\title{
РЕЦЕНЗИИ
}

\section{Stalinism, Boyars and the Russian Tradition}

\author{
A. Yu. Dvornichenko
}

For citation: Dvornichenko A. Yu. Stalinism, Boyars and the Russian Tradition. Vestnik of Saint Petersburg University. History, 2018, vol. 63, issue 2, pp. 636-647. https://doi.org/10.21638/11701/ spbu02.2018.218

The author of this review engages in controversy not only with the book by J. Arch Getty, but also with the representatives of this trend in historiography, both western and eastern. Undoubtedly, there are a number of archaic traditions in the Soviet Union and contemporary Russia as far as their political, economic and cultural foundations are concerned, especially in comparison with the Western countries. Without some definition and studying of these traditions one could not understand a peculiarity of the Russian political system. Here the author of the review agrees with the book. But it is important to define what archaic tradition is and what we are studying. J. Arch Getty and some specialists in Political Science try to find those traditions in so called 'political practices'. They affirm that such traditions are as old as the hills. It is this approach that causes disagreement. In the reviewer's opinion, nothing changes in the Russian history but the 'political practice', which really can be transformed. Having said that, we must show what this 'nothing' is. Although the Russian history is indivisible, it consists of some epochs which are different from one another. What hasn't undergone changes is the state-serfdom Russian order which took shape in the middle of the $17^{\text {th }}$ century and exists nowadays. In his review the author criticizes some cliché of Political Science. Such magic clues for Russian history as 'patrimonialism' and the 'patron-client relations' cause doubts. As far as the former is concerned, it is so vague that can be applicable to anything. For this reason it is not very harmful to the study of Russia. But one can't say so about the latter. Being adopted by History from Anthropology, this theory has been very popular among some Russian and foreign historians. The author once more stresses the significance of anthropological data and their role in the historical research. But some anthropological data taken from their historical and cultural context may have a detrimental impact on scholarship. The author does not want to accuse Getty because he is a talented and diligent scholar, and his great desire to understand contemporary Russian history evokes only sympathy. But we have to take into account

Andrey Yu. Dvornichenko - Doctor in History, Professor, St. Petersburg State University, 7-9, Universitetskaya nab., St. Petersburg, 199034, Russian Federation; a.dvornichenko@spbu.ru

Андрей Юрьевич Дворниченко - д-р ист. наук, проф., Санкт-Петербургский государственный университет, Российская Федерация, 199034, Санкт-Петербург, Университетская наб., 7-9; a.dvornichenko@spbu.ru

(C) Санкт-Петербургский государственный университет, 2018 
the historical approach, in other words, historicism, otherwise we can distort the historical perspective.

Keywords: J. Arch Getty, Stalinism, political practices, patrimonialism, patron-client relations, historicism.

\title{
Сталинизм, бояре и русская традиция
}

\section{А. Ю. Дворниченко}

Для цитирования: Dvornichenko A. Yu. Stalinism, Boyars and the Russian Tradition // Вестник Санкт-Петербургского университета. История. 2018. Т. 63. Вып. 2. С. 636-647. https://doi. org/10.21638/11701/spbu02.2018.218

\begin{abstract}
Автор данной рецензии вступает в полемику не только с Арчем Гетти, творчество которого, кстати, достаточно высоко оценивает, но и с целым направлением в современной науке, имеющим своих адептов не столько среди историков, сколько среди политологов и социологов. Впрочем, с некоторыми утверждениями данного направления автор рецензии согласен, как говорится, по определению. То, что история России буквально пронизана архаикой, и Советский Союз, как и современную Россию, без учета и внимательного изучения архаических традиций не понять, не вызывает сомнений. Сомнения возникают как раз на стыке разных обществоведческих дисциплин, которые хотят понять эти традиции. Дело в том, что возникает настоятельная необходимость разобраться с тем, что такое архаическая традиция, как она меняется, как соотносится со своим древним архетипом. Другими словами, в России ничего не меняется, но это тот самый случай, когда исследователи должны четко понять, что стоит за этим «ничего». Нужно соблюдать принцип историзма, по крайней мере в смысле уважения к исторической науке. Те ученые, с которыми дискутирует автор рецензии, изучают прежде всего так называемые «политические практики», которые под их пером приобретают характер некоей константы, не меняющейся по мере того, как одна эпоха в России сменяется другой. Одновременно они играют роль своего рода «магических ключей» к пониманию политической системы России. Но, как считает автор рецензии, именно эти самые политические практики таковой константой и не являются. Неизменным (в своей основе) остается только тот государственно-крепостнический строй, который сформировался в России к середине XVII столетия, а потом продолжал развиваться и укрепляться. Да и ключом к пониманию политического устройства России «патримониализм» и клановая система также вряд ли могут служить. Первое слишком расплывчато, а второе, временами выдвигаясь на передний план, никогда не определяло политическую систему страны.
\end{abstract}

Ключевые слова: Арч Гетти, сталинизм, политические практики, патримониализм, патрон-клиентские отношения, историзм.

I have great esteem for American Russian Studies and respect American historians, enthusiastic scholars specializing in this field, the study of which, I suppose, is not funded any longer by the State Department as much as it was during the Cold War. Also, my mother says that Americans are very similar to Russians. Indeed, I feel there is some resemblance between the Russians and the Americans even in terms of scholarly work, because they also prefer generalizations and some bold hypotheses, broad statements, deep reflection. and so on. However, Plato is my friend, but truth is more my friend.

All these thoughts (and many others) occurred to me, when I was reading the book by the well-known professor of California University in Los-Angeles (UCLA), doctor 
J. Arch Getty. This book is like mature wine, because it was published some years ago ${ }^{1}$, but recently has been translated into Russian ${ }^{2}$ and, of course, it is not an accident. What makes it important is that this book written by a talented man reflects one of the trends in American Russian Studies, which is not very old but significant in academic terms. The dialogue with this historian is the conversation with the whole trend... The author himself says that he 'stands on the shoulders of the giants'. One can find this phrase in the book written by Robert Crummey, where it refers to our prominent scholar, the founder of the Petersburg historical school, Sergei Platonov. Getty alludes to Western historians and sociologists whose works comprise the theoretical foundation of his book. Among these giants there are Merl Fainsod with the famous "How the Soviet Union is governed", Edward L. Keenan, T.H. Rigby and Pierre Bourdie with his sociology.

Steven White convinced Getty of the fact that political modernization does not necessarily entail economic and social modernization ${ }^{3}$, Ken Jowitt showed that being modern at first sight, the Soviet political system was full of traditional features, introducing the term "Neotradicionalism"4. And, of course, "whether we want it or not, we are all Weberianists" . On the whole, there is a sound theoretical background, and Getty can't be criticized for the lack of theory ${ }^{6}$.

Getty sincerely wants to understand the political system and political history of Russia and uses not only historiography and historical sources for his analysis, but also his knowledge of Russian life gained through his first-hand experience in Russia, when he worked in archives and libraries, and established friendly contacts with the Russians. He tries to secure himself at the same time and says that a foreign author writing about Russia looks slightly presumptuous. Has he been able to find the essence of this strange, but undoubtedly modern, society ${ }^{7}$ ? Let us try to understand this situation. It is all the more important because this book has been criticized in printed ${ }^{8}$ and electronic editions ${ }^{9}$.

Getty's main notion is that Russian political system is full of archaic traditions. Such position appeals to the Russian historians who also wanted to understand the phenomenon of Russia. When we lived behind the "Iron Curtain" in a socialist state which was about to transform into a communist stage, according to our rulers, we could not notice archaic features in our environment, the "deep patterns" of political behavior, as Edvard L. Keenan says ${ }^{10}$. American scholars were pioneers in this field of the knowledge, irrespective of the differences between revisionists and anticommunists. For example, Richard

${ }^{1}$ Getty Arch J. Practicing Stalinism. Bolsheviks, Boyars and the Persistence of Tradition. New Haven; London, 2013.

2 Getty A. Praktika stalinizma: Bol'sheviki, boyare i neumirayushchaya tradiciya / Arch Getty: [per. s angl. L. Yu. Pantinoj]. Moscow, 2016.

3 White S. Political Culture and Soviet Politics. Ch. 8. London, 1979.

${ }^{4}$ Jowitt K. Neotraditionalism: The Political Corruption of a Leninist Regime // Soviet Studies. 1983. Vol.35. N 3. P. 275-297.

5 Getty A. Praktika stalinizma. P. 16.

${ }^{6}$ Ibid. P. 32.

7 Ibid. P. 5.

8 David-Fox Michael. Review [ Practicing Stalinism: Bolsheviks, Boyars, and the Persistence of Tradition by J. Arch Getty] // Slavic Review. 2014. Vol.73, N 3. FALL. P. 635-638.

9 Zhezhko-Braun I. Konec istorii v otdel'no vzyatoi strane: Arch Getti ob arhaicheskih chertah rossijskoj politicheskoj praktiki ot Ivana Groznogo do Putina // Internet zhurnal «Gefter» 07. 04.2017 (gefter.ru) (accessed 28.07.2017).

${ }_{10}$ Though, it may be not "deep paterns", but "rooted habits of thinking and action", according to A. P. Tompson (Getty A. Praktika stalinizma. P.5]. 
Pipes, who took active part in the Cold War, being the adherer to the concept of 'patrimonialism, tried to explain the phenomenon of Soviet Russia resorting to the concept of "votchina state", which had emerged in medieval Russia ${ }^{11}$.

But to do us justice I want to say that at the beginning of the 1980s some historians and philosophers of Leningrad State University formed a group named "New Archaic" (compare with the "Neotraditionalism" by Ken Jowitt). Although we principally studied the archaic traditions in medieval Russia ${ }^{12}$, it was a step forward. Ten years late some Moscow historians also began to write about archaic traditions. One can refer to a very elegant article written by Sigurd Shmidt ${ }^{13}$ and some others.

That the Russian life is full of archaic features one can see by the naked eye. To observe this we don't have to leave Russian capitals: Moscow and Saint Petersburg. However, it is important to define what archaic tradition is, what we are studying. For Getty it is political practice, in other words, the "naked and intentional" functionality, which became a part of Russian culture and created the Russian specificity ${ }^{14}$. It is not so much the vitality of these elements or their revival, but the system itself which has its origins in the ancient past and continues to exist nowadays. This system is permeated with patrimonial tradition, in Max Weber's interpretation, and personalized policy. All these features comprise the essence of Russian political system, which is examined by Getty in some chapters connected with each other.

Getty deliberately does not take into account such important sphere of the social life as ideology, which has been pointed out by the critics of his book. It can be added that that he does not consider other spheres, such as economy, social struggle etc.

In the first chapter called "Old and New" the author studies "some eclectic practices and models of behavior" trying to understand the "underlying meaning" of the letters written by people to those in power. He postulates the resemblance between the old practice of "chelobitia" and contemporary "direct line" (call-in live show) with Putin. But to specialists in medieval Russia there are questions which arise, for example, about the origin of this tradition. Getty connected it to the influence of Mongols, but it was also known in the Great Duchy of Lithuania ${ }^{15}$ where the Mongols' influence was minimal. But there are more essential questions. What do these features tell us about the Russian political practice? What can the practice of glorification of Stalin in Soviet epic (resembling the format of "bylina") clarify? It is rather the feature of culture and mentality.

As far as the rewards are concerned, "rewards are rewards even in Africa" as the Russian saying goes. Even taking into account some Russian peculiarity, we can say that our country is not so deviant in this respect. But to connect the "objective guilt" in Stalin's Russia with the "krugovaia poruka" of Kievan Rus is an overstatement. "Mestnichestvo",

11 Pipes R. Russia under the Bolshevik Regime. New York, 1995. P. 503.

12 Froianov I. Ia., Dvornichenko A. Iu., Krivosheev Iu. V. The Introduction of Christianity in Russia and the Pagan Traditions // Soviet anthropology and archeology. 1991. Vol.29, iss. 3. Winter. P. 12-24.

13 Shmidt S. O. Srednevekov'e v gosudarstvennom stroe Rossii novogo vremeni // Obshchestvennoe samosoznanie rossijskogo blagorodnogo sosloviya, XVII - pervaya tret' XIX veka. Moscow, 2002. P.310322. Firstly this article was published at 1998.

14 Getty A. Praktika stalinizma. P. 30.

15 Dvornichenko A. Yu. Russkie zemli Velikogo knyazhestva Litovskogo (do nachala XVI v.). St. Petersburg, 1993. P. 171, 180. 
which had come from the East, hadn't survived its epoch due to Peter the Great's efforts. It's on these pages that Getty contemplates the risk of "overrating continuity"16.

The second chapter contains very interesting material about the cults of Russian rulers. The most fascinating part is devoted to the creation of Lenin' Mausoleum. This archival material is very compelling to readers, but the phenomenon of Lenin's Mausoleum requires further historical exploration. The difference between western and Russian tradition is obvious. Once I stopped near the Mausoleum of General Grant in New York and tried to imagine American rulers standing on this Mausoleum and greeting a demonstration of American workers. But if in Russia this is the reincarnation of some Eastern tradition, one can ask about the origin of it. Some scholars stressed the influence of Christianity. However, Georgii Fedotov revealed that in the Russian Orthodox Church the incorruptible relics were not deemed prerequisite of sanctity. So we don't know about the historical and cultural roots of the mummy of "grand-father Lenin". Also, we could not explain to which extent Soviet cults stem from famous "naive monarchism" of prerevolutionary times, and to which extent they reflect the influence of the new ideology. And who is right: Getty or Plamper ${ }^{17}$ ? The truth may be in the middle, but it has to be identified. Moreover, Getty's historical parallels here are not correct. The period after Stalin's death is hardly similar to the Times of Trouble (the beginning of the 17 century), and the image of the tsar as the owner of all Russia is a mistake ${ }^{18}$.

It is in this chapter that the 'magic clue' to all Russian political history appears. I mean the patron-client relationships and personal ties. Muscovy had been ruled by the network of such patron-clients groups, and nothing changed during the Imperial period. The reader is prepared to draw a conclusion that the same system existed in the USSR. But before making such conclusions, Getty in two chapters (third and fourth) studies the 'personnel system of the Party', examines this system in the "upper strata" and "law strata". He delves into the Russian sources and collects new, very interesting material here. Thus, with respect to the factual side I can only express my admiration. But with respect to theory, there are some remarks.

He compares the Soviet "nomenklatura" with the boyars and the d'iaks, but such a comparison gives nothing ${ }^{19}$. I do not understand what he wants to say. The abundance of small and insignificant questions in our power structures can be found in any epoch: it's enough to take a look at the Gosudarstvennaia Duma now. This is one of the evidence to support the idea that important decisions are usually taken in other places, in narrow groups - official and informal, behind the closed doors. But here the Russian originality in Getty's interpretation disappears. Such practice is known also in the USA, and even Thatcher and Stalin are identical in this situation: they can replace each other in this respect ${ }^{20}$. The next conclusion is also strange: Getty finds the difference between the upper "strata" of rulers and low strata. The "apparatus" (low strata) was in need of 'rational bureaucracy', but the upper elite preferred "patrimonialism" with its "arbitrary flexibility". If we refer to the above-mentioned Getty's comparison about d'iaks, I suppose that Moscow

16 Getty A. Praktika stalinizma. P.76.

17 Plamper J. The Stalin Cult: A Study in the Alchemy of Power. New Haven (Conn.), 2012.

18 Getty A. Praktika stalinizma. P. 92, 94.

19 Getty does not use the classical work of M.S. Voslenskii 'Nomenklatura' (several editions). To my mind it could be very useful to him for studying the Soviet power.

${ }^{20}$ Getty A. Praktika stalinizma. P. 128 
d'iaks, who spent their time seeking opportunities for bribes, would have been very surprised to know that they represented "rational bureaucracy"!

The rest of the book is devoted to the problem of emergence and development of the "clans", their support by Stalin and his struggle with them. According to Getty, these "clans" originated because of the scarcity of experienced party members and the minority of the "Bolsheviks" in general. It was due to such scarcity that the "Bolsheviks" formed groups around some powerful leaders, and "clans" were born. Political power was usually interpreted as personal and patrimonial. And if there was not one leader is some area, but several ones, the struggle among the "clans" was inevitable ${ }^{21}$. And if in the fifth chapter Getty studies, first of all, the struggle with so called opposition, from this perspective, in the three last chapters he describes "three rounds" of the sparring between Stalin and "the regional barons".

Stalin needed the existence of such "clans"22, and at the same time he was the typical "clan's leader" as other "barons" with whom he sparred. By the way, his belonging to some "clan" did not enable him to build a contemporary state in Russia ${ }^{23}$. Honestly, out of fear of a tyrant's anger I would rather not develop this theme further, but I want to ask Getty what "clan" Ivan the Terrible or Peter the Great belonged to? Apparently, these must have been "clans" of Rurik family and the Romanovs. However, it is not clear why the "clans" supported Stalin, but not the opposition, if there was no difference between them, particularly, from a provincial point of view ${ }^{24}$.

Thus, after showing a bright and broad picture of the struggle between "clans" inside the Ministry of Internal Affairs, Getty switches over to describing the relationships between Stalin and barons. He compares the leaders of the "clans" with some "small feudal princes" and Stalin's policy with the policy of Ivan the Terrible and simultaneously with that of Louis $14^{25}$. Getty has the predecessor here: Orlando Cappelli deemed the commissaries of Louis, Ivan's boyars and Stalin's representatives the "King's men", who had been sent by the kings to other areas since the time of Charlemagne ${ }^{26}$.

The "King's men" had a lot to do because the above-mentioned "clans" not only covered the crimes of many gangsters but also committed these crimes themselves. I think that it may have been the case in the Soviet Union, but not to such an extent. All the more so, as there are not many examples in Getty's book. However, these "clans", in the author's opinion, posed such danger that not only terrorized all local population and fought against the "King's men", but even began to struggle... with the famous Stalin's constitution of 1936. In the actual fact, they opposed the secret ballot, which posed a threat for their positions. However, in this case, it's not clear why after publishing the document about open and competitive elections, Politburo sanctioned the massive offensive against "kulaks"? The matter was that the "clans" and their barons were much afraid of "kulaks" menace. Stalin could have sent "kulaks" against "barons", but instead he launched the campaign against "kulaks". Some time ago he abolished the system of open and competitive

${ }^{21}$ Getty A. Praktika stalinizma. P. 158.

22 The existence of such "strong families" was a certain price for the stability and unity in the regional party committties (Getty A. Praktika stalinizma. P. 177).

${ }^{23}$ Getty A. Praktika stalinizma. P. 179, 215.

24 Ibid. P. 167.

25 Ibid. P. 194.

${ }^{26}$ Cappelli O. Pre-Modern State-Building in Post-Soviet Russia // Journal of Communist Studies and Transition Politics. 2008. Vol.24, N 4. P. 547, 561. 
elections and returned to a nomination of one candidate. And then he resolutely attacked insidious "barons". This onslaught had its culmination in the Great Purge of 1937-1938.

And here Getty makes one of the most dubious conclusions: the Great Purge was aimed at "barons". Getty, however, cannot understand why Stalin chose for this aim the summer of 1937. But a reader is in a worse situation because he does not understand why Getty arrives at this conclusion, given the obvious problem with the sources: there are many references to Stalin's quotes and other Moscow "centralizers", but the voices of the "barons" are not represented. Moreover, Getty's way of working with the existing sources is somewhat strange. For example, we have the list of the local leaders arrested in East Siberia. The separate lists for different branches, from the party lists to the lists of the NKVD clearly show that the "decapitation" of some establishments was accompanied by the arrests of the subordinates. But what does it prove? My grandfather worked as the head of one of the technical college in a famous Russian town of Veliky Ustyug located in the Russian North. He told me that at first all directors of all colleges were arrested, and then the majority of the teachers. What can we say? That every director had his own clan?

Of course, I am not an expert on the problems of Stalinism. It seems to me that Getty collected interesting material but the interpretation of this material is rather weak. According to such logic, we can say that the atrocities of Ivan the Terrible were directed at boyars only. By the way, some scholars tried to address the issue of oprichnina from the same perspective and... failed. I am sure that this concept, as Britons says, has completely gone out the window. It's clear that both Stalinism and Groznevizm manifested the explosion of violence against their own people and, therefore, were directed at all layers of the society. This is something which accompanies the "revolution from above", which from time to time occurs in our native land.

Surprisingly, the epilogue of the book plays a special role. However, it's not so strange because it is the epilogue that gives Getty some opportunity to extend the thread between Stalin's epoch and contemporary Russia. The latter gives abundance of scope for Getty in terms of description. He depicts a well-known picture of Russian vices: the total state control, the absence of civil rights, the corruption and so on. As a result, he finds the same supremacy of the "clans system" nowadays as it was during the rule of the Great Helmsman. Besides, his conception is more rigid than the one by Rigby. T.H. Rigby doubts the strength of personal ties in contemporary Russia but Getty considers that nothing has changed ${ }^{27}$. According to Getty, there are two powerful "clans" in Russia now: "siloviki" and "reformers" who fight with each other. This political situation evokes very strange associations in Getty's mind: with the struggle of Peter the Great against Moscow boyars, and with the controversy between the Slavophiles and the Westernizers. At the same time, in his opinion, the Russian rulers usually try to keep the balance: Andropov liked the jazz, and Putin, the former intelligence officer, prefers free market. Getty attempts at analyzing the "clans" struggle and then goes on to discussing the cult of Putin. It's strange but Getty observes analogies between tsar's habits and Putin's visits to Russian monasteries. He also incorporates D. Medvedev in this context.

Of course, this "cult" exists in reality, but we cannot forget about the differences between "old" and "new" cults ${ }^{28}$. After a brief review of the problem "President - gover-

27 Getty A. Praktika stalinizma. P. 282-283.

${ }^{28}$ Cassiday J. A. and Johnson E. D. Putin, Putiniana and the Question of a Post-Soviet Cult of Personality // The Slavonic and East European Review, Vol. 88, N 4. October, 2010. P. 681-707. 
nors", Getty defines commissioners of President as the "Kings men". He also finds the struggle for the "throne" in contemporary Russia. The reflection of this struggle is the well-known "Khodorkovskii's affair".

So, the "political practices" emerged in Muscovite Russia and haven't changed until nowadays, at any rate, on the whole. And how they are changing now is not quite clear $^{29}$. It's somewhat reassuring for Russian readers that such practices are observed not only in Russia, but also in Africa, and even in the actions of US presidents. In the "contemporary" states (original quotation marks by Getty. - A. D.) these practices gradually disappear with the strengthening of constitutional institutes, but not in Russia. Getty wonders why is this so? He alludes to the notorious underdeveloped Russian capitalism but then, as if in a gesture of despair and resolution, as Russians say, "dropping his cap to the ground" concludes that in most countries of the world there are no strong and independent institutions, and the authoritative constitutions are a rarity. So, then he changes his question. Now it is: "Why has Europe been modernized"? Again, the main reason is the powerful and all-embracing capitalism. However, capitalism by itself does not guarantee modern "political practices". For example, China is a quite a capitalistic system, but with strengthening of capitalism in this country, the traditions of corruption, political clans and patronage are cemented.

And there are some reasons for optimism, because some scholars consider that these patrimonial clientele networks are not only the inalienable part of a state system but it is the State itself! Russian readers can also be satisfied with the idea that institutions of all states are ephemeral, not only in Russia. Here Getty uses some very extravagant definitions of the State, particularly, the idea of Oleg Kharkhordin that a State is not some empirical reality, but rather a label which only characterizes the actions of the individuals $^{30}$. Or it may be Bourdieu's idea about State as a symbol ${ }^{31}$, and so on. And then the final conclusion is made: there were radical changes in Russia, in particular, throughout the XX century, contemporary Russia is fundamentally different from the USSR, but the "political practices" haven't changed.

I have some reservations concerning the magic clues for Russian history, particularly, "patrimonialism" and the patron-client relations. As far as the former is concerned, it is so vague that can be applicable to anything. For this reason it is not very harmful to the study of Russia. But I can't say so about the latter. Being adopted by History from Anthropology, this theory has been very popular among some Russian and foreign historians. I belong to such scholars who have always held in high esteem the data of Anthropology and their role in the historical research. But some anthropological data taken from their historical and cultural contexts may have a detrimental impact on scholarship. Some time ago I criticized this theory ${ }^{32}$.

The book written by the Russian sociology M. N. Afanas'ev ${ }^{33}$ played a role in spreading this theory, and Getty also refers to it. I turned to this book and noticed its superfici-

29 Getty A. Praktika stalinizma. P. 299.

${ }^{30}$ Kharkhordin O. What Is the State? The Russian Concept of Gosudarstvo in the European Context // History and Theory. 2001. Vol. 40. P.207-208.

31 Bourdieu P., Wacquant L. J. D. An Invitation to Reflexive Sociology. Chicago, 1992. P. 111.

32 Dvornichenko A. Yu. Rossiyu ponimat' umom? // Vestnik Sankt-Peterburgskogo universiteta. Istoriia. 2017. Vol.62, iss. 1. P. 206-208.

${ }^{33}$ Afanas'ev M. N. Klientelizm i rossijskaya gosudarstvennost': Issledovanie klientarnyh otnoshenij, ih roli v ehvolyucii i upadke proshlyh form rossijskoj gosudarstvennosti, ih vliyaniya na politicheskie instituty i deyatel'nost' vlastvuyushchih grupp v sovremennoj Rossii. Moscow, 2000. 
ality from a historical point of view. The author demonstrates shallow acquaintance with the Russian history. It is a pity that I have no opportunity to criticize this book now. The "clans theory" is inapplicable to the Russian history. J. R. Wedel compared East European politicians with the bigmen of Melanesia ${ }^{34}$. To my mind, Putin may or may not be big or even great man, but he is not just a bigman of a Melanesian tribe!

Sociologists usually distort the understanding of Russian history. So, American sociologist of Russian origin, V. Shlapentokh, wrote a book which was characterized by the reviewer as "the most complete and reliable picture of the social-political system of contemporary Russia" 35 . That this scholar also tried to find some remnants of ancient time in contemporary Russia is a very positive feature of his book. But he should have started with a proof that the theory of "feudalism" is a good model for studying Russian history. $\mathrm{He}$ failed to refute the doubts of some historians in the viability of the feudal "model" 36 . Whether intentionally or not, but he created a comical situation: the historians specializing in the medieval history, have already rejected the "feudal model" and this theory ${ }^{37}$, while sociologists have started to use it studying contemporary Russia: Shlapentokh's case is not solitary - some foreign and Russian specialists write in the same way ${ }^{38}$.

But, perhaps, more disturbance to historical knowledge is brought about by some specialists in Political Sciences. The above-mentioned Russian historian S. Shmidt said: "Political Study is always History" 39 . It is a very good idea! And politologists strive to bring history closer to Political Studies... but usually fail, their works are very far from the historical method. And Getty also from time to time says that nothing changes in Russia, that for ten centuries princes, tsars, general secretaries, presidents have ruled Russia with the help of detachments and clans ${ }^{40}$. Here "political culture" backfires on the historian. He, as many other scholars, is convinced of the existence of a certain "political culture" which does not change throughout centuries. In my opinion, any "political culture" doesn't exist beyond the historical context. It is the main mistake of Getty, and his critic was right writing: "It is ironic that political culture is the glue holding Getty's continuity argument together, for he is not at all concerned with the workings of culture, political or otherwise" 41 . It is where his main mistake lies, and not in his excuses for Stalin or in his descriptions of the depressive way of development for Russia, as other critics consider. In the end, whether we love or not this "monster with a moustache", we must understand this History.

Here we can notice a reproduction of a previous controversy concerning the wellknown article by one of Getty's predecessors, Edward L. Keenan, which was entitled "Mus-

34 Wedel J. R. Collision and Collusion: The Strange Case of Western Aid to Eastern Europe. New York, 1998. P. 106.

35 Sheregi F. Razmyshleniia o knige Vladimira Shliapentoha «Sovremennaia Rossiia kak feodal’noe obshchestvo» // Teleskop: zhurnal sociologicheskikh i marketingovykh issledovanii. 2010. N 1. P. 57.

36 Shlyapentoh $V$. Sovremennaya Rossiya kak feodal'noe obshchestvo. Novyj rakurs postsovetskoj ehry. Moscow, 2008. P. 46.

${ }^{37}$ Ivonin A.R. Tupiki «russkogo feodalizma» // Obshchestvennye nauki i sovremennost'. 2011. N 2. P. $87-100$.

38 The Shlapentokh's conception was detailed criticized by well-known specialist in medieval Russian history Charles J.Halperin (Halperin Ch. J. Feudalism in Russia, Then and Now: Vladimir Shlapentokh's Concept of a 'Feudal Society' // Studia Slavica et Balcanica Petropolitana. 2015. N 2(18). P. 208-225).

39 Shmidt S. O. Srednevekov'e v gosudarstvennom stroe Rossii novogo vremeni. P. 322.

40 Getty A. Praktika stalinizma. P. 276.

${ }^{41}$ David-Fox Michael. Review. P. 635. 
covite Political Folkways"42. Robert Daniels noted: “...Unfortunately the understanding of 'culture' is not so simple, and the concept of political culture, as it has been propounded by political scientists, is even less simple". He also rightly considers that "... we need a more historically oriented conception of political culture as well as of culture in general" 43 .

It is not so much the fear and apprehension of the authors at the time. It was and it is the historical method which must come to the fore. The drawback of the specialists in Political Science, as Richard Wortman noticed, is that in their works "History becomes the building material for a model that leaves out historical process" 44 . And it is not a coincidence that that it was Wortman's remarks that Keenan had difficulty arguing with adequately ${ }^{45}$.

For this reason the borrowings from Keenan's article did not strengthen the base of Getty's theory. The article by the well-known historian Richard Hellie didn't help him either. The main flaw of this work is not even the artificial conception of three instrumental revolutions in the Russian history, but the artificial blending of different epochs. For example, he funnily connects different phenomena: "The abuse of Soviet and post-Soviet soldiers, the notorious dedovshchina was foretold by the treatment of draftee recruits in the eighteenth-century Russian army" 46 and so on.

The absence of historical approach is typical of the specialists in Political Science. Another example: Russian scholar Oleg Kharkhordin connects the practice of public penitence of Stalin's time with the early Christian ritual (exomologesis); so-called oblichenie common during the Stalin's rule is traced back by him to the Ortodox Christian tradition, and so on ${ }^{47}$. What could I say? The "Moral Code of the Builder of Communism" also reminds Jesus Christ's "Sermon on the Mount", but is it enough to state that the Bolsheviks took this Code from Christianity? And even if they did, does it tell us much about their habits and ways? Again, we see the same attempt to consider some practice taken out of the historical context.

One more mistake of the scholars, particularly, from the West: they apply the domestic notions to Russia. And when they put up the radical question "How Russia (Soviet Union, Russian Empire etc) is (was, will be) governed?" they even cannot imagine that from time to time it is not governed at all: the State Power leads its own life and the People - their own.

I have no wish to accuse Getty because he is a talented and diligent scholar, and his great desire to understand contemporary Russian history evokes only my sympathy. But we have to take into account the historical approach, in other words historicism, otherwise, we can distort the historical perspective.

${ }^{42}$ Keenan E.L. Muscovite Political Folkways // The Russian Review. 1986. Vol.45, N 2. April. P.115181.

${ }^{43}$ Daniels R. V. Russian Political Culture and the Post-Revolutionary Impasse // The Russian Review. 1987. Vol. 46, N 2. April. P. 166, 168.

44 Wortman R. "Muscovite Political Folkways" and the Problem of Russian Political Culture // The Russian Review. 1987. Vol.46, N 2. April. P. 193.

${ }^{45}$ Keenan E.L. ["Muscovite Political Folkways"]: Reply // The Russian Review. 1987. Vol.46, N 2. April. P. 208-209.

46 Hellie R. The Structure of Russian Imperial History // History and Theory. 2005. Vol. 44, N 4. Theme Issue 44: Theorizing Empire. December. P. 95.

47 Kharkhordin O. The Collective and the Individual in Russia. A Study of Practices. Berkeley; Los Angeles; London, 1999. P. 67-70, 217-228. 
We can say that in Russian history nothing has changed over the centuries. But it is that occasion when we must show what this "nothing" is. Russian history consists of some epochs which are different from one another, even though this history is indivisible. Geoffrey Hosking correctly named so called Kievan Rus a prelude, the very different history ${ }^{48}$. I suppose that this period is the Antiquity of the East Slavs ${ }^{49}$. And since ancient time the political system, undoubtedly, has changed. I am sure, for example, that the meetings of townsmen in Russian towns in the $17^{\text {th }}$ century differ from so called "veche" in the towns of Kievan Russia $\left(9^{\text {th }}-12^{\text {th }} c\right)$. Yes, in Russian history nothing changes but it is the "political practice" which can be really transformed. What has not changed is the state-serfdom Russian order which took shape in the middle of $17^{\text {th }}$ century and exists nowadays ${ }^{50}$.

\section{References}

Afanas'ev M. N. Klientelizm i rossijskaya gosudarstvennost': Issledovanie klientarnyh otnoshenij, ih roli v ehvolyucii $i$ upadke proshlyh form rossijskoj gosudarstvennosti, ih vliyaniya na politicheskie instituty i deyatel'nost' vlastvuyushchih grupp v sovremennoj Rossii. Moscow, Moskovskij obshchestvennyj nauchnyj fond Publ., 2000. 318 p. (In Russian)

Bourdieu P., Wacquant L. J.D. An Invitation to Reflexive Sociology. Chicago, University of Chicago Press, $1992.348 \mathrm{p}$.

Cappelli O. Pre-Modern State-Building in Post-Soviet Russia. Journal of Communist Studies and Transition Politics, 2008, vol. 24, no. 4, pp. 531-572.

Cassiday J.A., Johnson E.D. Putin, Putiniana and the Question of a Post-Soviet Cult of Personality. The Slavonic and East European Review, 2010, vol. 88, no. 4, October, pp. 681-707.

Crummey R. O. The Formation of Myscovy 1304-1613. London, New York, Longman, 1987. 275 p.

David-Fox Michael. Review [Practicing Stalinism: Bolsheviks, Boyars, and the Persistence of Tradition by J. Arch Getty]. Slavic Review, 2014, vol. 73, no. 3, Fall, pp. 635-638.

Daniels R.V. Russian Political Culture and the Post-Revolutionary Impasse. The Russian Review, 1987, vol. 46, no. 2, April, pp. 165-175.

Dvornichenko A. Yu. The Place of the Kievan Rus in History. Vestnik of Saint Petersburg University. History, 2016, vol. 4, pp. 5-17. (In Russian)

Dvornichenko A. Yu. Russkie zemli Velikogo knyazhestva Litovskogo (do nachala XVI v.). St. Petersburg, Publishing House of the St. Petersburg University, 1993, 204 p. (In Russian)

Dvornichenko A. Yu. Rossijskaya istoriya s drevnejshih vremyon do padeniya samoderzhaviya. Moscow, Ves’ Mir Publ., 2010, 944 p. (In Russian)

Dvornichenko A. Yu. Can Russia be grasped with the mind? Vestnik of Saint Petersburg University. History. 2017, vol. 62, issue 1, pp. 201-214. (In Russian)

Froianov I. Ia., Dvornichenko A. Yu., Krivosheev Yu. V. The Introduction of Christianity in Russia and the Pagan Traditions. Soviet anthropology and archeology. 1991, vol. 29, iss. 3, Winter, pp. 12-24.

Getty Arch J. Practicing Stalinism. Bolsheviks, Boyars and the Persistence of Tradition. New Haven, London, 2013, 384 p. (Russ. ed.: Getty A. Praktika stalinizma: Bol'sheviki, boyare i neumirayushchaya tradiciya. Moscow, ROSSPEN Publ., 2016, 374 p.).

Halperin Ch. J. Feudalism in Russia, Then and Now: Vladimir Shlapentokh's Concept of a "Feudal Society". Studia Slavica et Balcanica Petropolitana. 2015, no. 2(18), pp. 208-225.

Hellie R. The Structure of Russian Imperial History. History and Theory, 2005, vol. 44, no. 4, theme issue 44: Theorizing Empire, December, pp. 88-112.

Hosking G. Russian History: A Very Short Introduction. Oxford; New York, Oxford University Press, 2012. $154 \mathrm{p}$.

Ivonin A. R. Tupiki «russkogo feodalizma». Obshchestvennye nauki i sovremennost'. 2011, no. 2, pp. 87-100. (In Russian)

${ }^{48}$ Hosking G. Russian History: A Very Short Introduction. Oxford; New York, 2012. P. xvi.

49 Dvornichenko A. Yu. The Place of the Kievan Rus in History // Vestnik Sankt-Peterburgskogo universiteta. Istoriia. 2016. Vol. 4. P. 5-17.

50 Dvornichenko A. Yu. Rossijskaya istoriya s drevnejshih vremyon do padeniya samoderzhaviya. Moscow, 2010. 
Jowitt K. Neotraditionalism: The Political Corruption of a Leninist Regime. Soviet Studies, 1983, vol. 35, no. 3, pp. 275-297.

Keenan E. L. Muscovite Political Folkways. The Russian Review, 1986, vol. 45, no. 2, April, pp. 115-181.

Keenan E.L. ["Muscovite Political Folkways"]: Reply. The Russian Review, 1987, vol. 46, no. 2, April, pp. 199-209.

Kharkhordin O. What Is the State? The Russian Concept of Gosudarstvo in the European Context. History and Theory, 2001, vol. 40, pp. 206-240.

Kharkhordin O. The Collective and the Individual in Russia. A Study of Practices. Berkeley; Los Angeles; London, University of California Press, 1999, 406 p.

Pipes R. Russia under the Bolshevik Regime. New York, Vintage Books, a division of Random House, 1995, $587 \mathrm{p}$.

Plamper J. The Stalin Cult: A Study in the Alchemy of Power. New Haven (Conn.), Yale University Press. 2012, $352 \mathrm{p}$.

Sheregi F. Razmyshleniya o knige Vladimira Shlyapentoha "Sovremennaya Rossiya kak feudal'noe obshchestvo". Teleskop: zhurnal sociologicheskih i marketingovyh issledovanii, 2010, no. 1, pp. 57-59. (In Russian)

Shlyapentoh V. Sovremennaya Rossiya kak feodal'noe obshchestvo. Novyj rakurs postsovetskoj ehry. Moscow, Stolica-Print, 2008. 367 p. (In Russian)

Shmidt S. O. Srednevekov'e v gosudarstvennom stroe Rossii novogo vremeni. Obshchestvennoe samosoznanie rossijskogo blagorodnogo sosloviya, XVII - pervaya tret' XIX veka. Moscow, Nauka Publ., 2002, pp. 310-322. (In Russian)

White S. Political Culture and Soviet Politics. London, Macmillan, 1979, 234 p.

Wedel J. R. Collision and Collusion: The Strange Case of Western Aid to Eastern Europe. New York, St. Martin's Press, 1998, $286 \mathrm{p}$.

Wortman R. "Muscovite Political Folkways" and the Problem of Russian Political Culture. The Russian Review, 1987, vol. 46, no. 2, April, pp. 191-197.

Received: 28.08 .2017

Accepted: 30.03 .2018 